\title{
DIÁKOK ÉLELMISZERFOGYASZTÁSI SZOKÁSAINAK VIZSGÁLATA NEMZETKÖZI VISZONYLATBAN ${ }^{1}$
}

\author{
Panyor Ágota - Lendvai Edina - Gál József
}

\section{SUMMARY}

The present study examines the context of a competition won (Leonardo da Vinci), the young people's eating habits. Within the framework of research online questionnaire we filled up with students from the countries participating in the project, including 465 evaluable substances. In our study, we analyzed the students' preferences and food consumption of traditional foods and their motivations for fast food.

\section{BEVEZETÉS}

A 2012-ben indult Leonardo da Vinci „Integration of Culture and Health Knowledge into the Vocational Education of Food and Beverages" projekt keretében felmérést készítettünk diákok táplálkozási szokásai tekintetében. A projektben résztvevő országok diákjait kérdeztük meg, így a válaszadóink Magyarországon kívül Törökországból, Romániából, Lengyelországból, Hollandiából és Walesböl kerültek ki. Vizsgáltuk az élelmiszerfogyasztásuk rendszerességét, a fogyasztás összetételét, ezen belül a leggyakrabban fogyasztott élelmiszereket, valamint az élelmiszerfogyasztás helyszíneit. Kiemelten hangsúlyt helyezve a gyorséttermi fogyasztási szokásokra. Az étkezés jelentős szerepet kap a különböző népek kultúrájában, büszkék tradícióikra, nemzeti ételeikre. Ennek ellenére megállapítható, hogy az ételek Európa különböző részein nem feltétlenül térnek el egymástól, így a nemzeti étel fogalma vitatható (Rátz 2004, Michalkó 2004, Burkáné Szolnoki 2003, Gelman 2012, Szende 1994).

A felmérésben online kérdöívet töltöttek ki az előzőekben említett országok diákjai, akik a 14-21 éves korosztályhoz tartoznak. Az értékelhető kérdőívek száma $465 \mathrm{db}$ volt, amely az evasys rendszer kiértékeléssel került feldolgozásra.

\section{A KUTATÁS EREDMÉNYEI}

A megkérdezettek átlagéletkora 19,63 év, a nemek szerinti megoszlás tekintetében a fiúk aránya $57,7 \%$, a lányoké pedig $42,3 \%$. Az országonkénti válaszadók száma igen eltérő, 30 fötől 150 föig terjedően.

A válaszadókat megkérdeztük azzal kapcsolatban, hogy naponta hányszor illetve milyen rendszerességgel étkeznek. Az 1. ábra adataiból kitünik, hogy a megkérdezettek közel fele (47\%) naponta háromszor étkezik és 15\%-ot képvisel azoknak az aránya, akik rendszertelenül étkeznek. Mindössze a megkérdezettek $20 \%$-a vallotta azt, hogy naponta 4-5-ször étkezik, amely az egészséges táplálkozás alapját jelenti.

\footnotetext{
${ }^{1}$ Ezen publikáció a Leonardo da Vinci Partnership Programban, az Integration of Culture and Health Knowledge into the Vocational Education of Food and Beverages project (HU-2012-LeoPA-6127) keretében végzett felmérésböl vette adatait.
} 


\section{1. ábra: A megkérdezettek megoszlása az étkezés rendszerességét tekintve}

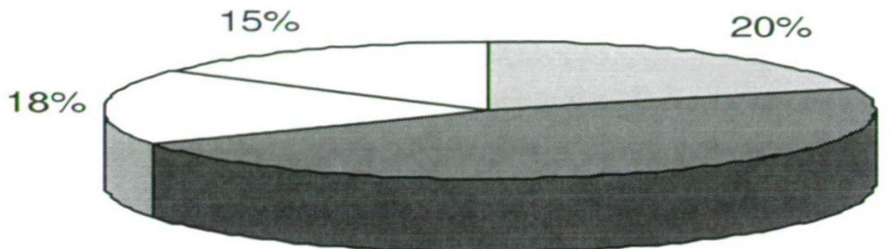

$47 \%$

\section{napi 4-5 $\square$ napi $3 \square$ kevesebb mint $3 \square$ rendszertelen}

Forrás: Leonardo da Vinci projektbeli felmérés alapján

Kutatásunkban vizsgáltuk, hogy az egyes élelmiszereket milyen gyakorisággal fogyasztják a megkérdezett diákok. A leggyakrabban fogyasztott élelmiszerek között találjuk a kenyeret és a péksüteményeket, valamint a tejtermékeket és a zöldség, gyümölcsöket. Az édességek a felsorolásban csak a 6. helyen szerepelnek, tehát a fiatalok körében nem a leginkább preferáltak. Azonban nagyon kedvezően itélhetjük meg, hogy a zöldség és gyümölcsfélék kiemelt prioritást kapnak a mindennapi táplálkozási szokásokban (1. táblázat).

\section{1. táblázat: Az egyes élelmiszerek fogyasztási gyakorisága (átlagpont)}

\begin{tabular}{|l|c|}
\hline Élelmiszerek & Átlag \\
\hline Kenyér, péksütemény & 3,95 \\
\hline Tej, tejtermék & 3,74 \\
\hline Zöldség & 3,72 \\
\hline Gyümölcs & 3,69 \\
\hline Fehérhús & 3,45 \\
\hline Édesség & 3,44 \\
\hline Vöröshús & 3,13 \\
\hline Csipsz & 2,87 \\
\hline Hal, tengergyümölcsei & 2,51 \\
\hline Olajos magvak & 2,51 \\
\hline Müzli & 2,20 \\
\hline
\end{tabular}

Forrás: Leonardo da Vinci projektbeli felmérés alapján 
A megkérdezett diákok az esetek 39\%-ában gyakran az élvezet kedvéért is táplálkoznak (2. ábra). Azonban az elöző kérdésre adott válaszok alapján megállapíthatjuk, hogy ez nem egyértelmüen az édességekre értendő, hanem a például a gyümölcsök kínálta élvezeti értékekre is vágynak.

\section{2. ábra: Az élvezet kedvéért történő táplálkozás gyakorisága}

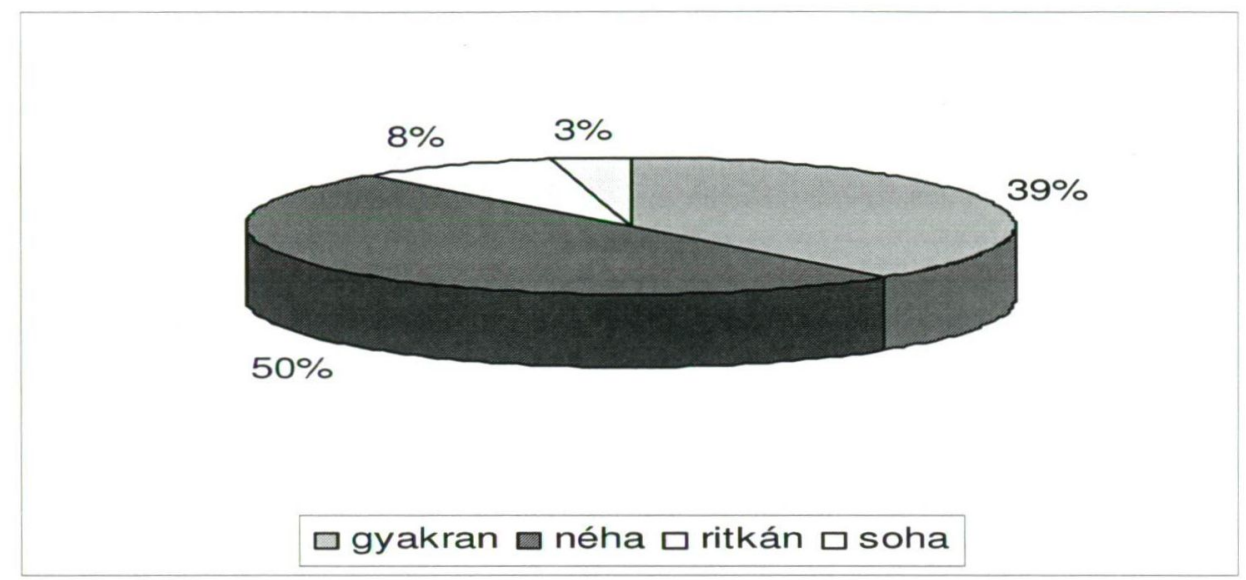

Forrás: Leonardo da Vinci projektbeli felmérés alapján

Kutatásunkban arra is választ kerestünk, hogy mennyire vannak megelégedve saját testtömegükkel a megkérdezett diákok. Közel 33\% azt gondolja, hogy ideális a testsúlya, mindössze $15 \%$ véli úgy, hogy fogynia kellene, és csak 3,4\% véli túlsúlyosnak magát (3. ábra).

\section{3. ábra: A válaszadók elégedettsége a testtömegük alapján}

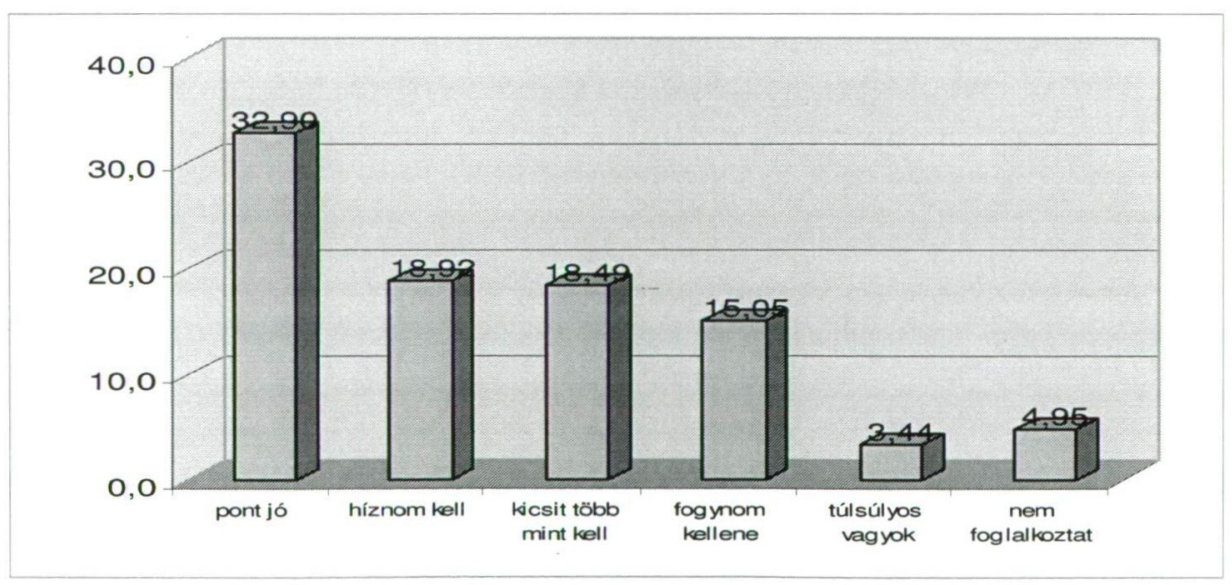

Forrás: Leonardo da Vinci projektbeli felmérés alapján 
A következő két kérdés kapcsán arra próbáltunk választ keresni, hogy a diákok a hétköznapokban és a hétvégén hol fogyasztják az ebédjüket, milyen környezetben étkeznek. A kérdésekre kapott válaszokat a 4. és az 5. ábra szemlélteti.

\section{4. ábra: A diákok megoszlása a hétköznapi ebédelés alapján}

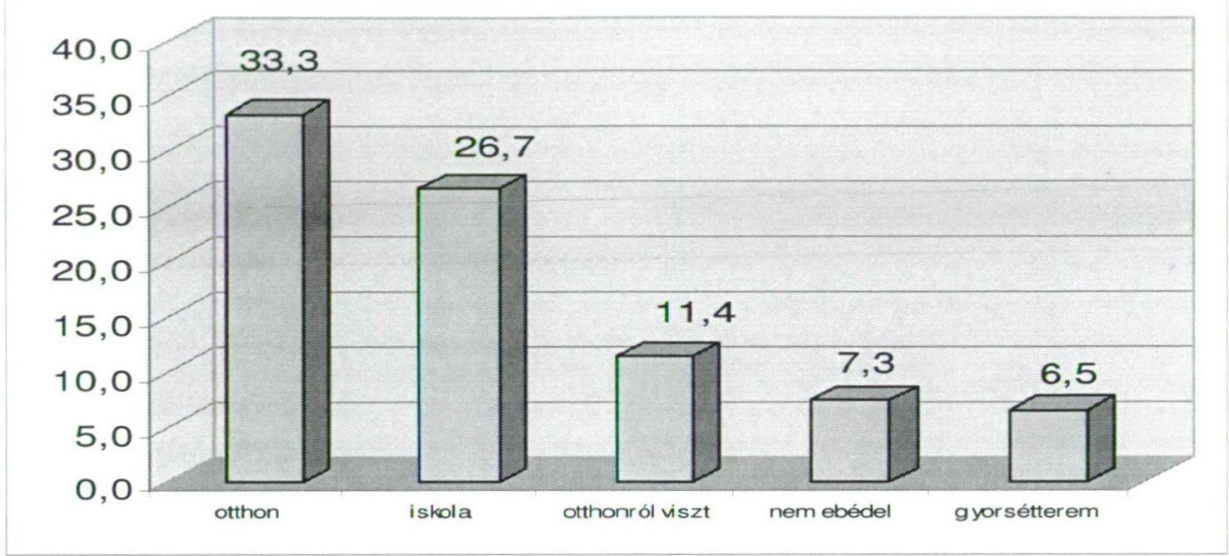

Forrás: Leonardo da Vinci projektbeli felmérés alapján

A megkérdezett fiatalok 33,3\%-a hétköznapok is tud otthon ebédelni, míg $26,7 \%$ az iskolai étkezést részesíti előnyben. A gyorséttermet a válaszadók 6,5\%-a jelölte csak meg. Hétvégén már a diákok 77,2\%-a ebédel otthon a családdal. Közel azonos arányban, azaz 6,2\% még a hétvégén is a gyorséttermeket részesíti elönybe.

\section{5. ábra: A diákok megoszlása a hétvégi ebédelés alapján}

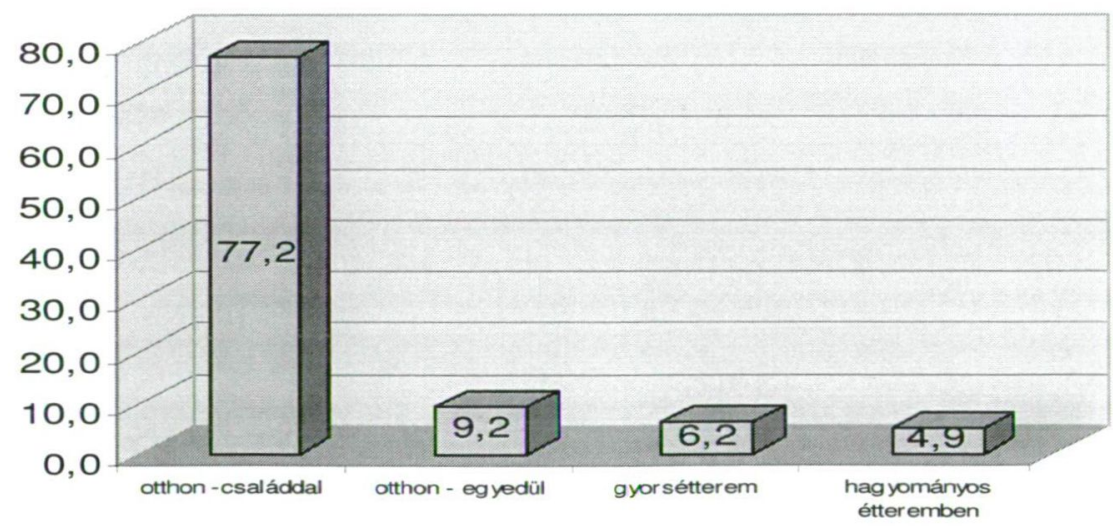

Forrás: Leonardo da Vinci projektbeli felmérés alapján 
Megfogalmaztunk 4 állítást, amelyben arra voltunk kíváncsiak, hogy milyen különbségeket tapasztalnak a hagyományos és a gyorséttermi ételek között. Egyértelmủen megállapíthatjuk, hogy a diákok drágábbnak találják a hagyományos éttermeket, mint a gyorséttermeket, és sokan választják a gyorséttermi étkezéseket is (2. táblázat). A megkérdezettek $88,9 \%$-a olyan városban lakik, ahol van gyorsétterem. A válaszadók 1/3-a havonta 1-2 alkalommal megy csak gyorsétterembe, a másik 1/3 hetente legalább egy alkalommal. A fiúk sokkal gyakrabban járnak, mint a lányok. A leggyakrabban a klasszikus hamburger-kólasültkrumpli menüt fogyasztják.

\section{2. táblázat: Az egyes állításokkal való egyetértés átlagértékei}

\begin{tabular}{|l|c|}
\hline Állítás & Átlagpont \\
\hline $\begin{array}{l}\text { Hagyományos étterem menüje drágább, mint a } \\
\text { gyorsétteremé }\end{array}$ & 3,68 \\
\hline $\begin{array}{l}\text { Az újrahasznosított csomagolás fontos } \\
\text { számomra }\end{array}$ & 3,42 \\
\hline $\begin{array}{l}\text { Ha nincs pénzem a kedvelt menüre, olcsóbbat } \\
\text { veszek }\end{array}$ & 2,91 \\
\hline $\begin{array}{l}\text { Jobban szeretem a gyorséttermet, mint a } \\
\text { hagyományosat }\end{array}$ & 2,62 \\
\hline
\end{tabular}

Forrás: Leonardo da Vinci projektbeli felmérés alapján

\section{3. ÖSSZEFOGLALÁS}

Kutatásunk során megállapítható, hogy a vizsgált országokban élő diákok táplálkozási szokásai viszonylag rendszeresnek mondhatóak és jellemzően az egészséges, naponta többszöri étkezést részesítik elönybe. Kedvenc ételeik közé tartoznak a péksütemények, a tejtermékek, valamint a zöldség és gyümölcsfélék is. A legtöbben otthon és az iskolában étkeznek, de jelentős arányt képviselnek a gyorséttermekbe járók köre is. Több fiú, mint lány jár gyorsétterembe. A diákok önmaguk testsúlyáról alkotott képe és a gyorséttermekbe való járás között lehet összefüggést felfedezni.

\section{IRODALOMJEGYZÉK}

Burkáné Szolnoki Á. (2003): Vendéglátó szakmai alapismeretek, Képzőművészeti Kiadó, Budapest.

Lauren, G. (2012): How Nutritionists Eat Fast Food http://www.prevention.com/food/healthyeating-tips/what-nutritionists-order-fast-food-restaurants; 2014.02.15.

Michalkó G. (2004): A turizmuselmélet alapjai, Turizmus Akadémia, Székesfehérvár.

Rátz T. (2004): European Tourism, KJF, Székesfehérvár, pp. 99-104.

Szende P. (1994): Marketing a szállodaiparban, KIT, Budapest. 